\title{
An Archaeological Assessment (Phase I) of the West Salado Creek Outfall Project, Southeastern Bexar County
}

Ronald W. Burkett

Jeffery A. Huebner

Follow this and additional works at: https://scholarworks.sfasu.edu/ita

Part of the American Material Culture Commons, Archaeological Anthropology Commons, Environmental Studies Commons, Other American Studies Commons, Other Arts and Humanities Commons, Other History of Art, Architecture, and Archaeology Commons, and the United States History Commons

Tell us how this article helped you.

This Article is brought to you for free and open access by the Center for Regional Heritage Research at SFA ScholarWorks. It has been accepted for inclusion in Index of Texas Archaeology: Open Access Gray Literature from the Lone Star State by an authorized editor of SFA ScholarWorks. For more information, please contact cdsscholarworks@sfasu.edu. 


\section{An Archaeological Assessment (Phase I) of the West Salado Creek Outfall Project, Southeastern Bexar County \\ Creative Commons License \\ (c) (1) (9)}

This work is licensed under a Creative Commons Attribution-NonCommercial 4.0 International License 


\section{AN ARCHAEOLOGICAL ASSESSMENT (PHASE I) OF THE WEST SALADO CREEK OUTFALL PROJECT, SOUTHEASTERN BEXAR COUNTY, TEXAS}

Ronald W. Burkett and Jeffery A. Huebner

Center for Archaeological Research The University of Texas at San Antonio Archaeological Survey Report, No. 181 1989 



.





\section{AN ARCHAEOLOGICAL ASSESSMENT (PHASE I) OF THE WEST SALADO CREEK OUTFALL PROJECT, SOUTHEASTERN BEXAR COUNTY, TEXAS}

Ronald W. Burkett and Jeffery A. Huebner

Texas Äntiquities Committee Permit No. 715

Center for Archaeological Research The University of Texas at San Antonio® Archaeological Survey Report, No. 181 
The following information is provided in accordance with the General Rules of Practice and Procedure, Chapter 41.11 (Investigation Reports), Texas Antiquities Committee:

1. Type of investigation: survey and limited subsurface testing;

2. Project name: West Salado Creek Outfall;

3. County: Bexar County, Texas;

4. Principal investigator: Jack D. Eaton;

5. Name and location of sponsoring agency: Seligmann and Pyle Consulting Engineers, Inc., 3918 Naco-Perrin, San Antonio, Texas 78217;

6. Texas Antiquities Committee Permit No. 715;

7. Published by the Center for Archaeological Research, The University of Texas at San Antonio, Texas 78285-0658, 1989.

A list of publications by the Center for Archaeological Research can be obtained by sending $\$ 1.00$ to the Center for Archaeological Research, The University of Texas at San Antonio, San Antonio, Texas 78285-0658. 


\begin{abstract}
During August 1988, a cultural resources pedestrian survey was conducted within the West Salado Creek Outfall pipeline easement (two-mile long by 50 -foot wide) in southeastern Bexar County, Texas. As a result of surface examination and limited subsurface shovel tests, one prehistoric site (41 BX 785) was recorded. Although some lithic debitage and burned rock fragments were found in the shovel tests at the prehistoric site, there was not enough information from the limited tests to determine if the site is intact. Further testing is recommended to determine if the site is potentially eligible to be nominated to the National Register of Historic Places or to be designated as a State Archeological Landmark.
\end{abstract}


TABLE OF CONTENTS

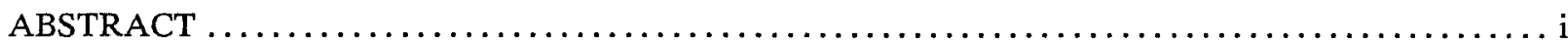

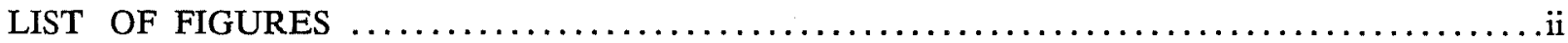

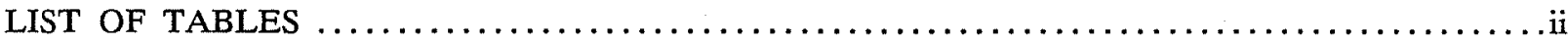

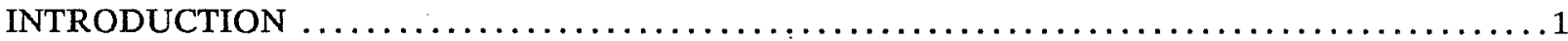

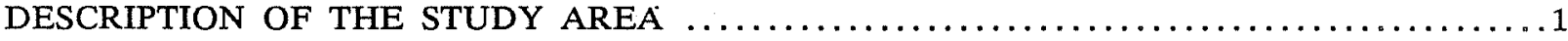

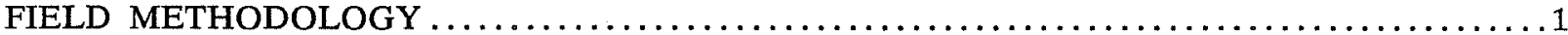

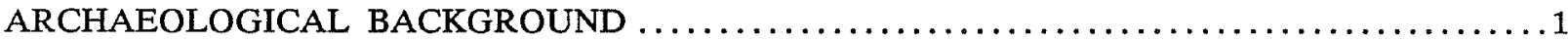

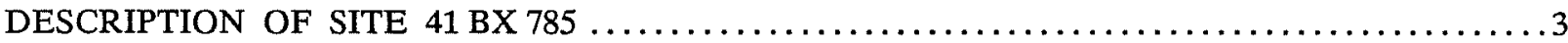

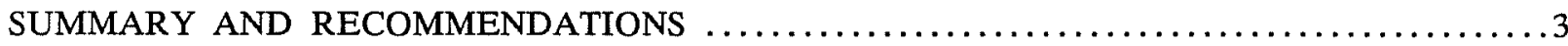

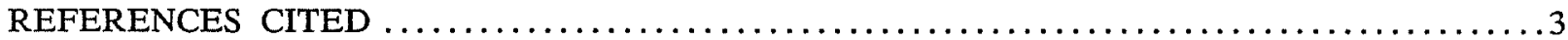

\section{LIST OF FIGURES}

1. Location of the West Salado Creek Outfall Survey Area and Archaeological Site 41 BX $785 \ldots \ldots 2$

\section{LIST OF TABLES}

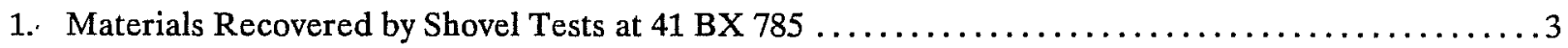




\section{INTRODUCTION}

During August 2-3, 1988, personnel from the Center for Archaeological Research (CAR), The University of Texas at San Antonio (UTSA), conducted a pedestrian survey and limited shovel testing along the 10,000-foot right-of-way of the West Salado Creek Outfall pipeline easement in southeastern Bexar County, Texas. The survey was conducted under contract between Seligmann and Pyle Consulting Engineers, Inc. (for the City of San Antonio), and the CAR-UTSA (letter dated July 26, 1988).

The purpose of the survey was to identify cultural resources that would be impacted by subsurface pipeline construction. Texas Antiquities Committee Permit No. 715 was issued for the project.

The field investigations were carried out by Jeffery A. Huebner and Ronald W. Burkett of the Center staff, under the general supervision of Jack D. Eaton, CAR acting director. All field notes, photographs, and other information pertinent to this project are curated at' the CAR-UTSA.

\section{DESCRIPTION OF THE STUDY AREA}

The West Salado Creek Outfall pipeline easement generally parallels a two-mile stretch of the modern Salado Creek channel in southeastern Bexar County. The survey area extends from Southcross Boulevard on the north to a point approximately $600 \mathrm{~m}$ north of Southeast Military Drive (Loop 13) on the south (Fig. 1).

The study area is situated along the lower Salado Creek floodplain and first terrace ca. six miles upstream from its confluence with the San Antonio River. This area of the county is nearly level or an undulating plain, sloping upward, southeast to northwest from 500 to 1000 feet in elevation.

Whereas the soils in the northern section of the county are thin and eroded over limestone, those of the southern portion are deep loamy sands and clays. The soils in the study area belong to the Venus-Frio-Trinity association. These soils are deep, calcareous soils on bottomlands and terraces.

Soils within the stream channel consist of Frio series limy alluvium. This soil is moderately deep grayish brown to dark grayish brown and nearly level. Adjacent terraces are Venus clay loam forming gentle slopes toward the creek (Taylor, Hailey, and Richmond 1966).

Urbanization has had a major impact on the study area. Extensive contour shaping projects within the northern one-third of the study area have been completed to facilitate the construction of a golf course and residential subdivisions. The central one-third lies in a graded roadway that was cut out of a steep section of bluff. The southern one-third has been impacted by residential subdivision construction on the west bank of Salado Creek and agricultural modifications on the east bank.

The patterns of local flora and fauna have been greatly modified by the urbanization of the study area. The native flora of the area is characteristic of the Tamaulipan Biotic Province (Blair 1950). Vegetation in the floodplain area is generally thick and composed of both native fauna and imports that have washed downstream from the areas to the north.

\section{FIELD METHODOLOGY}

An intensive pedestrian survey of the project area was conducted by the CAR staff, accompanied by a representative of Seligmann and Pyle Consulting Engineers, Inc. This escort was needed because the rightof-way was not marked. While the survey crew found some areas difficult to traverse due to the dense vegetation, the entire right-of-way was inspected and assessed.

The survey was accomplished by two persons spaced at 8- to $10-\mathrm{m}$ intervals. Subsurface testing was conducted with shovel probes in suspected site areas as evidenced by surficial cultural materials.

\section{ARCHAEOLOGICAL BACKGROUND}

In recent years, Bexar County has been the focus of a great deal of archaeological research. Within this corpus of information, relatively little has been done in this study area and the southern portion of Bexar County. South of the project area on Salado Creek, five small sites were identified during the San Antonio 201 Wastewater Treatment Project survey (Fox 1977). One of these sites, $41 \mathrm{BX} 124$, at the confluence of Medina Creek and the San Antonio River, was tested. While the surface collection contained materials from the early stages of the Archaic (Gower dart points and Guadalupe tools) through the Late Prehistoric (Scallom and Edwards arrow points), little was recovered from excavation (Valdez 1979). It was suspected that cultural remains of this surficially eroded site were buried deepin the terrace deposits (Fox, McGraw, and Valdez 1978). For additional information on previous archaeological research in Bexar County, the reader may consult reports by Black and McGraw (1985) for the northern portion of the county, and McGraw and Hindes (1987) for the southern portion.

The occupation and exploitation of Bexar County cover the period from 9200 B.C. to the present. While no local chronology has been established for the 
This page has been

redacted because it

contains restricted

information. 
survey area, the sequence of local periods established by Black and McGraw (1985:322, Table 55) for the upper Salado Creek watershed would seem the most useful.

\section{DEŚCRIPTION OF SITE 41 BX 785}

A single new site was recorded during the survey. A record check of the Texas Archeological Research Laboratory's site files identified no previously recorded sites in the project area.

Type of Site: Prehistoric occupational site.

Dimensions: Unknown. Limited subsurface testing was confined to the 50-foot-wide easement.

Location: The site is located on the west side of Salado Creek and approximately $900 \mathrm{~m}$ north of Military Drive (Loop 13). UTM coordinates 5670 4850.

Topographic Context: The site is on a low, generally level, stream terrace approximately $70 \mathrm{~m}$ from the modern Salado Creek channel.

Elevation: 559 feet above mean sea level (the elevation is given in feet to conform with standard topographical map contour intervals).

Site Discussion: The site was first recognized by a fairly uniform light lithic scatter over most of the 100$\mathrm{x} 100$-m stream terrace. This scatter included bifacially worked chert fragments, utilized flakes, and miscellaneous chert debitage. Three $50-\mathrm{cm}$ shovel test pits were dug along the pipeline right-of-way. Chert fragments were found to a depth of 35 to $40 \mathrm{~cm}$ in all three pits. Of particular interest was the discovery of some burned limestone rocks at a depth of $25 \mathrm{~cm}$ in two of the three test pits (see Table 1).

TABLE 1. MATERIALS RECOVERED BY SHOVEL TESTS AT 41 BX 785

\begin{tabular}{|c|c|c|}
\hline $\begin{array}{l}\text { Shovel Probe } \\
\text { Number }\end{array}$ & Depth & Materials Recovered \\
\hline 1 & $35 \mathrm{~cm}$ & $\begin{array}{l}1 \text { biface fragment } \\
1 \text { core fragment } \\
1 \text { tertiary flake }\end{array}$ \\
\hline 2 & $35 \mathrm{~cm}$ & $\begin{array}{l}2 \text { decorticate chips } \\
2 \text { secondary flakes }\end{array}$ \\
\hline & & $\begin{array}{l}1 \text { tertiary flake } \\
5 \text { burned rocks (limestone) }\end{array}$ \\
\hline 3 & $40 \mathrm{~cm}$ & $\begin{array}{l}6 \text { decorticate chips } \\
2 \text { burned rocks (limestone) }\end{array}$ \\
\hline
\end{tabular}

\section{SUMMARY AND RECOMMENDATIONS}

After completion of a pedestrian survey of the entire West Salado Creek Outfall right-of-way, one prehistoric site (41 BX 785) was recorded. Although chert flakes were present, no diagnostic artifacts were recovered from the surface or the shovel tests. However, the finding of burned limestone fragments at a uniform depth and some $30 \mathrm{~m}$ apart, might indicate the possibility of an intact occupation level at the site. Should this be the case, it might provide a rare opportunity for prehistoric research at an undisturbed site in this area of Bexar County. The shovel tests did not provide enough information to determine if the site is actually intact and potentially eligible for designation as a State Archeological Landmark or for nomination to the National Register of Historic Places. Therefore, we recommend that further testing be done.

In regards to a research design, we recommend that the following research be implemented to determine if $41 \mathrm{BX} 785$ is indeed an intact site that is likely to provide significant cultural information, as opposed to a possible scatter of materials from a destroyed site in the area. The research design might need revision in the field as testing proceeds.

The estimated main portion of the site appears to lie within the easement as indicated by the shovel tests. The site should be gridded using a surveying instrument and at least six $1-\mathrm{m}^{2}$ test units selectively placed within the grid for the purpose of determining its subsurface integrity, depth, stratification, chronology, and to assess the potential importance of the site. If the site is intact and potentially important, appropriate recommendations for any further studies will be made.

\section{REFERENCES CITED}

Black, S. L. and A. J. McGraw

1985 The Panther Springs Creek Site: Cultural Change and Continuity within the Upper Salado Creek Watershed, South-Central Texas. Center for Archaeological Research, The University of Texas at San Antonio, Archaeological Survey Report 100.

Blair, W. F.

1950 The Biotic Provinces of Texas. The Texas Joumal of Science 2(1):93-113. 
Fox, A. A.

1977 An Archaeological Assessment of the San Antonio 201 Wastewater Treatment Project. Centerfor Archaeological Research, The University of Texas at San Antonio, Archaeological Survey Report 41.

Fox, A. A., A. J. McGraw, and F. Valdez, Jr.

1978 Archaeological Survey and Testing of Pipelines and Confluence Site, San Antonio 201 Wastewater Treatment Project. Center for Archaeological Research, The University of Texas at San Antonio, Archaeological Survey Report 66.

McGraw, A. J. and K. Hindes

1987 Chipped Stone and Adobe: A Cultural Resources Assessment of the Proposed Applewhite Reservoir, Bexar County, Texas. Center for Archaeological Research, The University of Texas at San Antonio, Archaeological Survey Report 163.

Taylor, F. B., R. B. Hailey, and D. L. Richmond

1966 Soil Survey of Bexar County, Texas. United States Department of Agriculture, Soil Conservation Service, in cooperation with the Texas Agricultural Experiment Station, Series 1962(12).

Valdez, F., Jr.

1979 A Summary of Recent Survey and Testing Activities in Southern Bexar County, Texas. La Tierra 6(1):3-10. 
